\title{
Picture and Picture to Improve Descriptive Writing Skills in Class IV of Pretek 01 Elementary School
}

\author{
Timbul Prabowo
}

SDN Pretek 01

timbulprabowo0979@gmail.com

\section{Article History}

accepted 01/11/2020

approved 08/11/2020

published 15/11/2020

\begin{abstract}
The purpose of this study was to improve teacher skills, increase student activity, and improve student description writing skills with the Picture and Picture strategy. This classroom action research was conducted in two cycles with the research subjects of class IV SD Pretek 01, totaling 28 students. The research data were in the form of quantitative data and qualitative data which were analyzed using descriptive analysis techniques. The variables of this study were (1) teacher skills, (2) student activities and (3) learning outcomes. From the research results, it can be seen that the teacher's skills in cycle 1 got a score of 90 and in cycle 2 got a score of 92. Student activity increased from cycle I 70.24 and cycle II 76.08 there was an increase. Student learning outcomes also increased. From 28 students who scored $\geq 75$ there were 13 students $(45 \%)$ in cycle II experienced an increase. $\geq 75$ there are 21 students (75\%)

Keywords: write descriptions, picture and picture strategies
\end{abstract}

\section{Abstrak}

Tujuan dari penelitian ini adalah untuk meningkatkan ketrampilan guru, meningkatkan aktivitas Peserta didik ,dan meningkatkan ketrampilan menulis deskripsi peserta didik dengan strategi Picture and Picture.Penelitian tindakan kelas ini dilakukan dalam dua siklus dengan subyek penelitian kelas IV SD Pretek 01 yang berjumlah 28 peserta didik. Data hasil penelitian berupa data kuantitatif dan data kualitatif yang dianalisis menggunakan teknis analisis deskriptif. Variabel penelitian ini adalah (1) keterampilan guru, (2) Aktivitas Peserta didik dan (3) hasil belajar. Dari hasil penelitian dapat diketahui bahwa ketrampilan guru pada siklus 1 mendapat skor 90 dan pada siklus 2 mendapat skor 92 . Aktivitas peserta didik meningkat dari siklus I 70,24 dan siklus II 76,08 ada kenaikan.. Hasil belajar siswa juga mengalami kenaikan dari 28 siswa yang mendapat nilai $\geq 75$ ada 13 siswa ( $45 \%$ ) pada siklus II mengalami peningkatan. $\geq$ 75 ada 21 siswa ( $75 \%$ )

Kata kunci: menulis deskripsi, strategi picture and picture

Social, Humanities, and Education Studies (SHEs): Conference Series https://jurnal.uns.ac.id/shes

p-ISSN 2620-9284

e-ISSN 2620-9292 


\section{PENDAHULUAN}

Pendidikan adalah usaha sadar dan terencana untuk mewujudkan suasana belajar dan proses pembelajaran agar peserta didik secara aktif mengembangkan potensi dirinya untuk memiliki kekuatan spiritual keagamaan, pengendalian diri, kepribadian, kecerdasan, akhlak mulia, serta keterampilan yang diperlukan dirinya, masyarakat, bangsa, dan negara. (Undang-undang Sisdiknas, 2003: 2).

Pembelajaran bahasa di sekolah menitikberatkan pada empat keterampilan

berbahasa. Keterampilan tersebut menurut Henry Guntur Tarigan meliputi keterampilan menyimak, berbicara, membaca dan menulis (1993: 1). Keempat keterampilan ini saling berhubungan dan saling menunjang satu sama lain. Hal itu dikarenakan keempat aspek tersebut sangat penting, pembelajaran bahasa dimasukkan dalam kurikulum mata pelajaran Bahasa Indonesia. Seperti yang tercantum dalam Kurikulum Tingkat Satuan Pendidikan yang disusun oleh Pusat Kurikulum Badan Penelitian dan Pengembangan Departemen Pendidikan Nasional (2006: 9), disebutkan bahwa salah satu tujuan mata pelajaran Bahasa Indonesia adalah siswa dapat berkomunikasi secara efektif dan efisien sesuai dengan etika yang berlaku, baik secara lisan maupun tertulis. Dari pernyataan tersebut tersirat bahwa keterampilan menulis cukup mendapatkan perhatian dalam pendidikan dan pembelajaran terutama di sekolah. Menulis merupakan kemampuan yang paling akhir dikuasai setelah peserta didik mampu menyimak, berbicara, dan membaca. Hal tersebut tidak mengherankan karena dalam menulis, peserta didik diharuskan untuk menguasai berbagai unsur kebahasaan dan unsur di luar bahasa itu sendiri sehingga tulisan yang dihasilkan dapat runtut dan padu, kohesif, dan kohern. Oleh karena itu, pembelajaran menulis ini harus diajarkan, dibina dan dikembangkan secara intensif di semua jenjang pendidikan.

Saat ini, pembelajaran menulis yang iadakan di sekolah-sekolah belum maksimal. Berdasarkan kenyataan di lapangan di SDN Pretek 01 KD 3.5 Indikatornya tidak tercapai karena peserta didik belum menemukan konsep tentang cara mengungkapkan pikiran dengan tulisan secara tepat. Peserta didik belum menemukan konsep mengidentifikasi masalah secara tertulis dengan tepat. Peserta didik belum menemukan cara menjelasan suatu contoh kegiatan secara tulisan.

Selain itu rendahnya kemampuan menulis deskripsi di sebabkan oleh beberapa faktor, diantaranya: (1) kurang antusiasnya siswa dalam mengikuti pelajaran menulis deskripsi; (2) siswa mengalami kesulitan dalam memahami materi menulis deskripsi; (3) siswa merasa jenuh atau bosan pada mata pelajaran bahasa Indonesia yang selama ini dilakukan secara monoton; (4) guru kesulitan membangkitkan keaktifan siswa; (5) guru belum menggunakan metode pembelajaran yang inovatif; (6) kurangnya pembimbingan guru saat siswa mengerjakan tugas menulis deskripsi; dan (7) guru kesulitan dalam menemukan dan menerapkan metode pembelajaran yang tepat dalam mengajar materi menulis deskripsi.

Permasalahan pembelajaran menulis deskripsi di SDN Pretek 01 ini dapat diatasi dengan penggunaan metode pembelajaran yang tepat agar dapat memperbaiki dan meningkatkan keterampilan siswa. Salah satu metode yang dapat digunakan untuk mengatasi masalah ini adalah dengan menggunakan metode picture and picture. Menurut Miftahul A'la (2011) picture and picture adalah suatu metode belajar yang menggunakan gambar dan dipasangkan atau diurutkan menjadi urutan yang logis.

Metode Pembelajaran picture and picture mengandalkan gambar sebagai media dalam proses pembelajaran. Gambar-gambar ini menjadi faktor utama dalam proses pembelajaran. Sehingga sebelum proses pembelajaran guru sudah menyiapkan gambar yang akan ditampilkan baik dalam bentuk kartu atau dalam bentuk carta dalam ukuran besar. Atau jika di sekolah sudah menggunakan ICT dalam menggunakan power point atau software yang lain (Sahrudin \& Sri Iriani : 2009). 
Model Picture and Picture merupakan suatu metode belajar yang menggunakan gambar yang dipasangkan atau diurutkan menjadi urutan logis (Hamdani, 2011: 89). Model Picture and Picture mengandalkan gambar sebagai media dalam proses pembelajaran. Suyatno (2004: 81) menyatakan bahwa penggunaan media gambar dalam pembelajaran menulis deskripsi bertujuan agar siswa dapat menulis deskripsi dengan cepat dan tepat. Media gambar dapat merangsang siswa agar lebih termotivasi dan tertarik dalam pembelajaran. Siswa dapat melihat secara langsung gambar yang akan dideskripsikan, sehingga siswa memperoleh kemudahan dalam kegiatan menulis deskripsi. Suprijono (2009: 125) mengemukakan langkah-langkah pembelajaran Picture and Picture, yaitu: guru menyampaikan kompetensi yang ingin dicapai, guru menyajikan materi sebagai pengantar, guru menunjukkan/memperlihatkan gambargambar yang berkaitan dengan materi, guru menunjuk/memanggil siswa secara bergantian memasang/mengurutkan gambar-gambar menjadi urutan yang logis, guru menanyakan alasan/dasar pemikiran urutan gambar tersebut, guru memulai menanamkan konsep/materi sesuai dengan kompetensi yang ingin dicapai, kesimpulan/rangkuman.

Berdasarkan identifikasi masalah di atas,maka permasalahan dalam penelitian ini di rumuskan sebagai berikut:"Apakah penerapan strategi pictureand picture dapat meningkatkan keterampilan menulis peserta didik kelas IV SD Negeri Pretek 01 pada tema Berbagai pekerjaan tentang Jenis-Jenis Pekerjaan?"

Berdasarkan rumusan masalah di atas, tujuan penelitian ini adalah untuk meningkatkan keterampilan menulis peserta didik Kelas IV SD Negeri Pretek 01 pada tema Berbagai Pekerjaan sub tema Jenis-jenis Pekerjaan dengan strategi picture and picture.

\section{METODE}

Penelitian ini dilakukan di SD Negeri Pretek 01 Kecamatan Pecalungan Kabupaten Batang. Alasan Peneliti memilih SD Negeri Pretek 01 sebagai tempat penelitian adalah karena mempertimbangkan kemudahan kerjasama antara peneliti, pihak sekolah, dan objek yang diteliti serta penghematan waktu dan biaya karena lokasi penelitian yang dekat dengan rumah peneliti pengajar. Penelitian dilaksanakan pada semester ganjil bulan Oktober tahun pelajaran 2020/2021. Tahap persiapan hingga pelaporan hasil penelitian akan dilakukan selama dua bulan, yakni mulai bulan Agustus 2020 sampai Oktober 2020. Yang menjadi subjek pada penelitian ini adalah siswa-siswi kelas IV SD Negeri Pretek 01 Kecamatan Pecalungan Kabupaten Batang Tahun Pelajaran 2020/2021 dengan jumlah siswa sebanyak 14 siswa putri dan 14 siswa putra.

Sumber data yang akan dimanfaatkan dalam penelitian ini adalah: (1) Informasi data yang diperoleh dari narasumber yang terdiri dari siswa kelas IV SD Negeri Pretek 01 Kecamatan Pecalungan Kabupaten Batang yang berjumlah 20 siswa dan guru kelas IV SD Negeri Pretek 01 Kecamatan Batang Kabupaten Batang. (2) Arsip dan Dokumen, arsip berupa kurikulum tingkat satuan pendidikan, sedangkan dokumen berupa data nilai ketrampilan menulis yang digunakan sebagai data nilai awal siswa kelas IV SD Negeri Pretek 01 Kecamatan Batang Kabupaten Batang sebelum dilakukan tindakan. (3) Hasil observasi ketrampilan menulis deskripsi pada siswa kelas IV SD Negeri Pretek 01 Kecamatan Batang Kabupaten Batang.

Penelitian ini menggunakan empat teknik pengumpulan data yang terdiri dari: Dokumentasi; Wawancara; Observasi; dan Tes. Menurut Suharsimi Arikunto (2010: 274) dokumentasi yaitu mencari data mengenai hal-hal atau variabel yang berupa catatan, transkip, buku, surat kabar, majalah, prasasti, notulen rapat, lengger, agenda, dan sebagainya. Menurut Suharsimi Arikunto (2010: 146) observasi adalah suatu kegiatan pemusatan perhatian terhadap sesuatu objek dengan menggunakan seluruh alat indera. Tes menulis dalam penelitian ini diberikan pada siswa kelas IV SD Negeri Pretek 01 Kecamatan Batang Kabupaten Batang dalam bentuk tes tertulis. 
SHEs: Conference Series 3 (3) (2020) $28-34$

HASIL DAN PEMBAHASAN

Kegiatan penelitian ini dilakukan dalam beberapa tahap yaitu kegiatan perencanaan, pelaksanaan, pengamatan, refleksi, serta keberhasian dan kegagalan lengkap dengan data. Rencana penelitian hasil perbaikan pembelajaran ketrampilan menulis deskripsi menjelaskan berbagai pekerjaan tentang Jenis-jenis pekerjaan dengan strategi Picture and Picture. Data hasil penelitian diambil dan diolah dengan statistik sederhana dalam bentuk tabel dan diagram. Pengambilan data hasil penelitian akan dilakukan penulis bekerjasama dengan teman sejawat dan dikonsultasikan kepada supervisor.Adapun pengolahan data hasil penelitian meliputi : (1) Hasil analisis evaluasi belajar tahap awal; (2) Hasil analisis evaluasi belajar siklus I; (3) Hasil analisis evaluasi belajar siklus II

Pelaksanaan pengolahan data hasil penelitian diawali dengan menampilkan tabel hasil analisis belajar tahap awal. Tabel ini dijadikan dasar pelaksanaan perbaikan pembelajaran siklus I dan siklus II. Adapun data hasil penelitian tersebut dijabarkan di bawah ini.

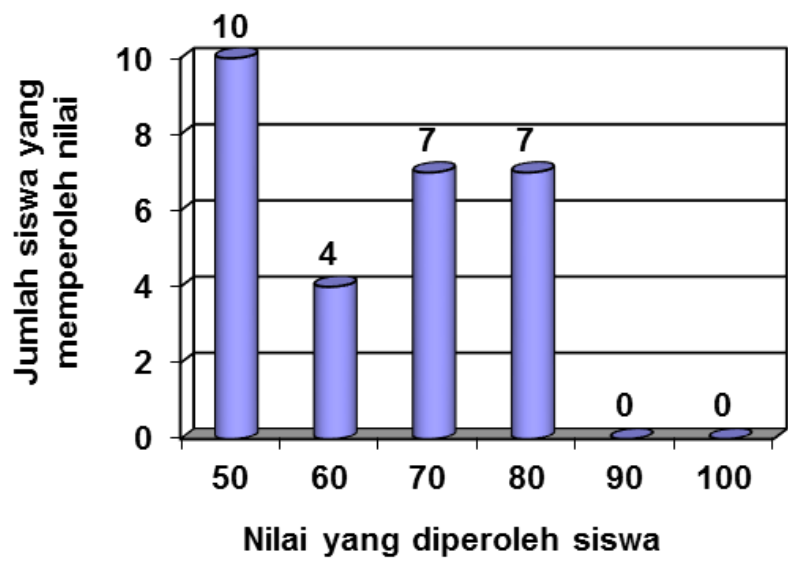

Gambar 1. Hasil Analisis Evaluasi Belajar Tahap Awal

Berdasarkan hasil evaluasi tahap awal ketrampilan menulis, penulis menyimpulkan bahwa hasil belajar siswa sangat rendah. Oleh karena itu penulis akan mencoba memperbaiki pembelajaran dengan mengadakan perbaikan pembelajaran siklus.Penulis berharap dengan melakukan perbaikan pembelajaran tersebut hasil prestasi belajar siswa akan meningkat.

Hasil evaluasi pada siklus I dapat dilihat pada gambar berikut:

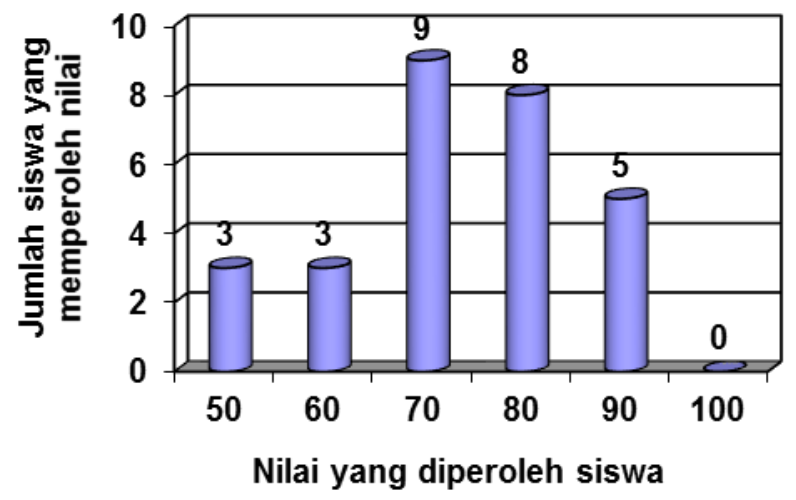

Gambar 2.Analisis Evaluasi Belajar Siklus I 
Berdasarkan perbaikan pembelajaran ketrampilan menulis siklus I, ternyata masih ada beberapa hal yang perlu diperbaiki lagi, antara lain masih ada siswa yang memperoleh nilai 50, sehingga untuk mencapai hasil yang lebih baik lagi penulis akan melaksanakan program perbaikan siklus II dengan fokus perbaikan pembelajaran melengkapi media berupa bagan agar setiap siswa dapat memanfaatkannya.

Hasil evaluasi pada siklus II dapat dilihat pada gambar berikut:

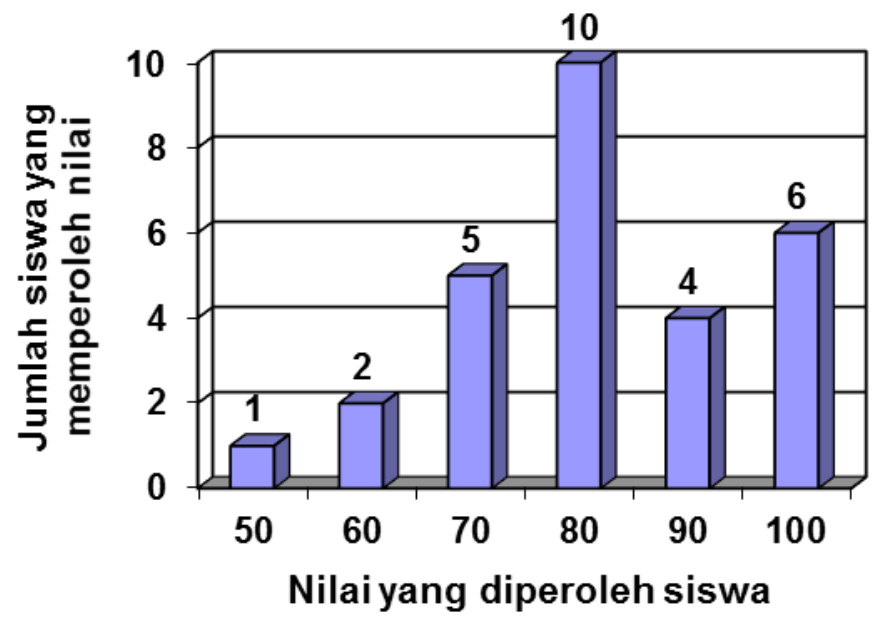

Gambar 3.Analisis Evaluasi Belajar Siklus II

Diagram di atas menunjukkan bahwa Ketuntasan belajar tertinggi dicapai pada siklus II yaitu $75 \%$. Berdasarkan pelaksanaan pengolahan hasil penelitian perbaikan pembelajaran ketrampilan menulis, ada beberapa hal yang dapat diamati, antara lain: Ada 8 (delapan) siswa yang masih mendapat nilai $<70$ atau belum tuntas. Ada beberapa siswa yang mengalami penurunan nilai dari tahap awal ke siklus I Secara klasikal pencapaian nilai dari tahap awal ke siklus I meningkat $21 \%$, dari siklus I ke siklus II meningkat $18 \%$.Pencapaian ketuntasan belajar dari tahap awal sampai siklus II mengalami peningkatan $50 \%$. Berdasarkan hasil pengamatan di atas menunjukkan bahwa perbaikan pembelajaran yang dilaksanakan secara keseluruhan mengalami keberhasilan. Adapun kegagalan yang dialami beberapa siswa sesuai pengamatan di atas dikarenakan: Kemampuan membaca dan memahami pelajaran kurang, sehingga memperoleh nilai belum tuntas. Penurunan nilai yang dialami oleh beberapa siswa dikarenakan kurang teliti dalam membaca dan memahami soal.

Setelah dilaksanakan perbaikan pembelajaran Ketrampilan menulis siklus selanjutnya dilakukan refleksi terhadap hasil perbaikan pembelajaran siklus I. Dari hasil refleksi tersebut diketahui bahwa dari jumlah 28 siswa yang mendapat nilai $>75$ ada 13 siswa (46\%) mencapai belajar tuntas. Sedangkan siswa yang mendapat nilai $<75$ ada 15 siswa (54\%) belum tuntas. Agar prestasi belajar siswa lebih meningkat, maka dilaksanakan siklus II.

Setelah dilaksanakan perbaikan pembelajaran ketrampilan menulis siklus II, selanjutnya dilakukan refleksi terhadap hasil perbaikan pembelajaran siklus II, dari hasil refleksi tersebut diketahui bahwa dari jumlah 28 siswa yang mendapat nilai $>75$ ada 21 siswa $(75 \%)$ atau mencapai belajar tuntas. Sedangkan siswa yang mendapat nilai $<75$ ada 7 siswa (25\%) atau belum mencapai belajar tuntas.

Berdasarkan hasil pelaksanaan perbaikan pembelajaran siklus II, ternyata sebagian besar siswa sudah mengalami kemajuan atau mencapai batas ketuntasan. Sebenarnya penulis ingin tetap meningkatkan prestasi siswa, terutama dalam pembelajaran Ketrampilan menulis dengan pendekatan Picture and picture, namun 
karena keterbatasan waktu dan tenaga penulis hanya melaksanakan program perbaikan pembelajaran sampai siklus II.

Berdasarkan pengamatan pelaksanaan perbaikan pembelajaran siklus I dan siklus II di atas ternyata ada peningkatan prestasi belajar siswa kelas IV SDN Pretek 01 Pecalungan Batang. Hal ini dikarenakan penggunaan metode eksperimen.

Dengan berhasilnya pelaksanaan perbaikan pembelajaran yang dilakukan membuktikan bahwa penelitian tindakan kelas dapat menjadikan guru lebih profesional. Seperti yang diutarakan oleh Abin Syamsudin bahwa guru profesional yaitu penampilan seorang guru yang sesuai dengan tuntutan yang seharusnya. Apabila setiap guru sudah profesional, setidaknya salah satu faktor keberhasilan pendidikan adalah faktor guru sudah memenuhi syarat tercapainya tujuan pendidikan.

Berdasarkan hasil penelitian di atas, diketahui bahwa ada banyak perubahan baik tingkah laku siswa maupun hasil pembelajarannya mulai dari siklus I hingga siklus II. Dari segi tingkah laku, siswa sudah dapat fokus dalam pembelajaran, dan sudah mulai membiasakan diri untuk aktif di kelas, selain itu dengan banyak latihan hasil menulis deskripsi siswa pun mengalami peningkatan. Hal ini sejalan dengan yang diungkapkan Hamalik (2013) yang menyatakan bahwa belajar adalah perubahan tingkah laku yang relatif mantap berkat latihan dan pengalaman. Perubahan menjadi lebih baik pada penelitian menulis deskripsi yang terjadi pada saat pembelajaran hanya dapat terencana saat guru dapat merencanakan kegiatan pembelajaran dengan baik dan menekankan pada pemahaman, keaktifan siswa, dan optimalisasi penggunaan sumber belajar.

Hasil penelitian ini sejalan dengan hasil penelitian sebelumnya yang dilakukan oleh Mundziroh (2012) yang menunjukkan bahwa (1) pembelajaran dengan menggunakan metode picture and picture pada pokok menulis cerita dapat meningkatkan keaktifan siswa kelas V SD Muhammadiyah 11 Mangkuyudan Surakarta. Keaktifan terlihat dari hasil observasi terhadap proses pembelajaran siswa yaitu, sebelum tindakan sebesar $27 \%$, siklus II sebesar $60 \%$ dan siklus II sebesar $80 \%$; (2) pembelajaran dengan menggunakan metode picture and picture dapat meningkatkan kemampuan menulis cerita siswa kelas V SD Muhammadiyah 11 Mangkuyudan Surakarta. Peningkatan kemampuan menulis cerita terlihat dari hasil pekerjaan siswa yaitu, sebelum tindakan sebesar $30 \%$, siklus I sebesar $60 \%$, dan pada siklus II sebanyak 83\%. Dewi (2019) juga menggunkaan model pembelajaran picture and picture berbantuan media visual dengan kelompok siswa yang dibelajarkan menggunakan pembelajaran konvensional pada siswa kelas III SD Gugus V Mengwi Tahun Ajaran 2018/2019. Rata- rata keterampilan menulis kelompok eksperimen lebih tinggi menunjukkan bahwa terdapat perbedaan keterampilan menulis kelompo ksiswa yang dibelajarkan menggunakan model picture and picture.

\section{SIMPULAN}

Dari serangkaian kegiatan yang penulis lakukan, dapat disimpulkan bahwa perbaikan pembelajaran yang terjadi dalam pembelajaran ketrampilan menulis diskripsi dapat membuat siswa aktif selama mengikuti proses pembelajaran. Kemudian setelah diadakan tes tertulis, prestasi hasil belajar siswa juga meningkat. Hal ini dapat dibuktikan dengan melihat diagram pencapaian hasil tes tertulis selama perbaikan pembelajaran yang dilakukan penulis pada setiap siklusnya selalu mengalami peningkatan di semua aspek. Dengan demikian maka kegiatan perbaikan pembelajaran yang dilakukan penulis telah mengalami keberhasilan yaitu dari jumlah 28 siswa yang mendapat nilai $\geq 75$ ada 22 siswa $(78 \%)$ atau mencapai belajar tuntas. Sedangkan siswa yang mendapat nilai $\leq 75$ ada 6 siswa $(22 \%)$ atau belum mencapai tuntas.

Ternyata penggunaan Strategi Picture And Picture dapat memperbaiki kelemahan-kelemahan maupun beberapa masalah yang muncul pada pembelajaran 
sebelum diadakan perbaikan, sehingga dalam kegiatan perbaikan proses pembelajaran dapat berjalan dengan baik, kelas menjadi hidup, siswa menjadi aktif dan tidak bosan serta dapat meningkatkan prestasi hasil belajar siswa.

Sehubungan dengan berhasilnya kegiatan perbaikan pembelajaran sebagaimana yang penulis simpulkanan di atas, maka dalam kaitannya dengan proses pembelajaran, dengan ini penulis memberikan beberapa saran yang ditujukan kepada: Guru dalam melaksanakan Kegiatan Belajar Mengajar hendaknya mengaktifkan siswa dalam penggunaan alat peraga. bosan serta dapat meningkatkan prestasi hasil belajar siswa.

\section{DAFTAR PUSTAKA}

A'la, M. (2011). Quantum Teaching. Jogjakarta : Diva Press.

Dewi, Ni Nyoman Krismasari, M.G Rini Kristiantari, Ni Nyoman Ganing (2019). Pengaruh Model Pembelajaran Picture and Picture Berbantuan Media Visual terhadap Keterampilan Menulis Bahasa Indonesia. Journal of Education Technology, 3 (4) pp. 278- 285

Hamdani. (2011). Strategi Belajar Mengajar. Bandung: Pustaka Setia.

Hamalik, O. (2013). Perencanaan Pengajaran Berdasarkan Pendekatan Sistem. Jakarta: Bumi Aksara.

Hamalik, O. (2013).. Proses Belajar Mengajar. Jakarta: Bumi Aksara.

Kurikulum Badan Penelitian dan Pengembangan Departemen Pendidikan Nasional. (2009). Peraturan Mendiknas tentang Satuan Pengawasan Internal (Permendiknas Nomor 47 tahun 2011). Jakarta: Penulis.

Mundziroh, Siti, Andayani, dan Kundharu Saddhono. (2013). Peningkatan Kemampuan Menulis Cerita dengan Menggunakan metode Picture and Picture pada Siswa Sekolah Dasar. BASASTRA Jurnal Penelitian Bahasa, Sastra Indonesia dan Pengajarannya. 2(1), 1-10.

Sahrudin \&Iriani, S. (2011). Model Pembelajaran Picture and Picture.

Suprijono, Agus. (2009) Cooperatif Learning: Teori dan Aplikasi, Yogyakarta: Pustaka Pelajar.

Suyatno. (2010). Teknik Pembelajaran Bahasa dan Sastra. Surabaya: Penerbit SIC.

Tarigan, H. G. (2008). Menulis Sebagai Suatu Keterampilan Berbahasa. Bandung: Angkasa. 